\title{
EFFECT OF ARBUSCULAR MYCORRHIZAL FUNGAL INOCULATION ON Eucalyptus globulus SEEDLINGS AND SOME SOIL ENZYME ACTIVITIES UNDER APPLICATION OF SEWAGE SLUDGE AMENDMENT
}

\author{
César Arriagada ${ }^{1}$, Patricio Pacheco ${ }^{1}$, Guillermo Pereira ${ }^{2}$, Angela Machuca ${ }^{2}$, \\ Marysol Alvear ${ }^{2}$ and Juan Antonio Ocampo ${ }^{4}$ \\ ${ }^{1}$ Departamento Ciencias Forestales, Facultad de Ciencias Agropecuarias y Forestales, Universidad \\ de La Frontera. Casilla 54-D, Temuco - Chile. ${ }^{2}$ Departamento Forestal, Sede Los Angeles, \\ Universidad de Concepción. ${ }^{3}$ Departamento Ciencias Químicas, Universidad de La Frontera. \\ Casilla 54-D, Temuco- Chile. ${ }^{4}$ Departamento de Microbiología, Estación Experimental de Zaidín, \\ CSIC, (18008) Granada, España. *Corresponding autor: carriaga@ufro.cl.
}

\begin{abstract}
The sewage sludge (SS) represents a source of organic matter although its increasing accumulation need a suitable environmental treatment. Our study analyzed the effect of the interaction between sewage sludge (doses $0,2,4,6$ and $8 \mathrm{~g}$ per $100 \mathrm{~g}$ of soil) and Eucalyptus globulus nursery seedlings inoculated with arbuscular mycorrhizal (AM) fungi as a fertilizers alternative and evaluate its effect on some soil enzyme activities. The seedlings were inoculated with Glomus claroideum, Glomus viscosum, Glomus intraradices and Glomus constrictum, establishing a uninoculated control. The sewage sludge application increased the shoot dry weight and the inoculation with G. viscosum was more effective at $6 \mathrm{~g}$ of SS in $100 \mathrm{~g}$ soil. The root colonization and succinate dehydrogenase activity was decreased by all doses of SS used. The Fluorescein diacetate activity was increased by the AM inoculation but not by sewage sludge. The

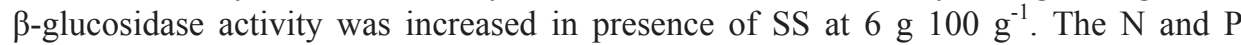
uptake by the E. globulus plants was higher in presence of sewage sludge and more effective with $G$. viscosum plant inoculation. In conclusion the application of these amounts of SS promoted the plant growth and can be regarded as a successful biotechnological tool for the greenhouse plant production.
\end{abstract}

Keywords: Biological fertilisers, Glomus, sewage sludge, soil enzymes, symbiosis

\section{INTRODUCTION}

The sewage sludge (SS) as a product of wastewater treatment is considered beneficial because improve soil fertility, biological parameters and plant nutrition. These residues with high nitrogen content enhance the soil productivity and can be used as fertilizer (Banerjee et al., 1997). In addition, the SS application improve the soil structure and fertility (Cuevas et al., 2000; Mata-González et al., 2002), but changes in soil microbial community in response to this application are not well 
known (Sullivan et al., 2006). Several authors show diverse responses of soil microorganisms to SS (Cuevas et al., 2000; García-Gil et al., 2004; MataGonzález et al., 2002). On the other hand, the SS can contribute to the rehabilitation of mineral sand mines (Rate et al., 2004) and the application to land offers an environmentally acceptable and agronomically favourable means of waste disposal (Oudeh et al., 2002).

Soil microorganisms are important in the recovery of disturbed and potentially toxic environments because they produce plant growth stimulating substances such as hormones and vitamins, bind soil particles into stable aggregates which improve soil structure, reduce erosion potential and can contribute to nutrient availability to plants (Shetty et al., 1994). The arbuscular mycorrhizal (AM) fungi are an important component of the soil microbial biomass. The symbiosis is mutualistic based on bidirectional nutrient transfer between the symbionts. The plant benefits particularly through enhanced phosphorus (Pearson and Jackobsen, 1993; Baon et al., 1992), nitrogen (Cliquet and Stewart, 1993), other mineral nutrients and water uptake, which often results in better growth. On the other hand, plants colonized by AM fungi also show an enhanced resistance to plant against several biotic and abiotic factors (Feng et al., 2002; Arriagada et al., 2004). It was reported that the AM fungi Glomus intraradices and Glomus deserticola and the addition of composted SS improve the growth and the $\mathrm{N}$ and $\mathrm{P}$ contents in shoot tissues of Juniperus oxycedrus (Alguacil et al., 2006). On the other side, the analyses of some biological parameters give more complete information on soil quality and health as affected by agricultural practices (Avidano et al., 2005). Research shows that fluorescein diacetate (FDA) hydrolysis and $\beta$ glucosidase are good indicators of soil biogeochemical processes. In fact, several authors used the hydrolysis of FDA to estimate microbial activities in soil (Schnürer and Roswall, 1982; Gumprecht et al., 1995; Bandick and Dick 1999). The $\beta$-glucosidase activity plays a key role in the $\mathrm{C}$ cycle, being positively related to total soil carbon and it was closely associated with microbial biomass (Alvear et al., 2005).

The aim of the present study was to determine the effect of SS application on the plant growth promotion by the AM fungi inoculation and measure the influence of this interaction on the biochemical parameters (fluorescein diacetate and $\beta$-glucosidase) in the rhizosphere soil.

\section{MATERIAL AND METHODS}

\section{Experimental design}

A design 5 x 5 full factorial randomized experimental design was used, including five mycorrhizal treatments: (1) uninoculated controls, (2) soil inoculated with Glomus claroideum, or (3) Glomus viscosum, or (4) G. intraradices, or (5) Glomus constrictum; and five SS doses: 0, 2, 4, 6 and $8 \mathrm{~g}$ per $100 \mathrm{~g}$ of soil. Ten replicate pots per treatment were used.

\section{Soil and sewage sludge}

The soil used in this study was an Andisol (Acrudoxic Hapludands) and was sampled from a 5- to $20-\mathrm{cm}$ depth (Ñielol soil series) at the relict native forest Rucamanque, $\left(\begin{array}{llll}38^{\circ} & 39^{\prime} \mathrm{S}, 72^{\circ} 35^{\prime} \mathrm{W}\end{array}\right)$, Temuco, Chile (Table 1). The samples were brought to the laboratory, sieved (2 $\mathrm{mm}$ ), and visible leaves branches and roots were eliminated. Field moistens soil 
samples were kept at $4^{\circ} \mathrm{C}$ in plastic containers until analysis.

The sewage sludge (SS) used was collected from municipal wastewater at Vilcún, Araucania Region, Southern of Chile. The main characteristics of the SS are showed in Table 2 .

\section{Biological material description}

Eucalyptus globulus Labill seeds previously surface-sterilised $\left(\mathrm{HgCl}_{2}\right.$ for $10 \mathrm{~min}$ ), and thoroughly rinsed with sterilized water, were sown in moistened sand. After germination, uniform seedlings were planted in $0.3 \mathrm{~L}$ pots filled with a mixture of sterilized sand:soil 1:4 v:v.

The arbuscular mycorrhizal (AM) fungi used in the experiment were $G$. laroideum (Schenck and Smith) Walker and Vestberg; G. viscosum T.H. Nicolson, $G$. intraradices Schenck \& Smith and $G$. constrictum Trappe, obtained from the culture collection at the Bioremediation laboratory of the University of $\mathrm{La}$ Frontera, Temuco, Chile.

\section{Arbuscular mycorrhizal inoculation of seedlings}

The AM fungal inoculum was prepared with a root and soil mixture consisting of rhizosphere soil containing spores and colonized root fragments of Medicago sativa L. in amounts of $8 \mathrm{~g}$ per pot, which were predetermined to achieve high levels of root colonization. A water filtrate (Whatman $\mathrm{N}^{\circ} 1$ paper) of the inoculum was applied to the uninoculated pots containing common soil microflora but free of AM fungal propagules. Plants were inoculated with AM fungi at transplantation (after 4 weeks of growth).

\section{Growth conditions}

Plants were grown in a greenhouse with supplementary light provided by Sylvania incandescent and cool-white lamps, $400 \mathrm{E}$ $\mathrm{m}^{-2} \mathrm{~s}^{-1}, 400-700 \mathrm{~nm}$, with a $16 / 8 \mathrm{~h}$ day/night cycle at $25 / 19^{\circ} \mathrm{C}$ and $70 \%$ relative humidity.

\section{Harvests and analyses}

Plants were harvested after 16 weeks and dry biomass of shoots and roots and nutrient concentration were determined. The $\mathrm{P}$ and $\mathrm{N}$ contents analysis were determined as described by Jackson (1973), after grinding the plant material to pass through a $0.5-\mathrm{mm}$ screen and digested in $\mathrm{H}_{2} \mathrm{SO}_{4}-\mathrm{H}_{2} \mathrm{O}_{2}$ mixture.

After the harvest, two samples of fresh roots were randomly taken from the entire root system. One of the samples was cleared and stained with trypan blue (Phillips and Hayman, 1970) and the percentage of root colonized by AM fungi was calculated by the gridline intersect method (Giovannetti and Mosse, 1980). In a second sample, succinate dehydrogenase (EC 1.3.99.1) (SDH) activity was measured in fungal mycelia through the reduction of tetrazolium salts at the expense of added succinate (MacDonald and Lewis, 1978). The percentage of AM fungal mycelia with SDH activity was determined under a compound microscope (Ocampo and Barea, 1985).

\section{Biochemical determinations}

The fluorescein diacetate activity (FDA) was assessed as described by Adam and Duncan (2001) and expressed as $\mu \mathrm{g}$ fluorescein released g-1 dry soil. $\beta$ glucosidase was determined by measuring 
Table 1: Chemical characteristics of soil sample

\begin{tabular}{lccccccc}
\hline Depth & $\mathrm{pH}$ & $\begin{array}{c}\mathrm{MO} \\
\%\end{array}$ & $\begin{array}{c}\mathrm{C} \\
\%\end{array}$ & $\begin{array}{c}\mathrm{N} \\
\mathrm{mg} \mathrm{kg}^{-1}\end{array}$ & $\begin{array}{c}\text { Olsen P } \\
\mathrm{mg} \mathrm{kg}^{-1}\end{array}$ & $\begin{array}{c}\mathrm{K} \\
\mathrm{mg} \mathrm{kg}^{-1}\end{array}$ & $\begin{array}{c}\mathrm{Al} \\
\mathrm{mg} \mathrm{kg}^{-1}\end{array}$ \\
\hline $5-20$ & 5.26 & 19.7 & 14.27 & 23.1 & 6.9 & 433 & $1,794.2$ \\
\hline
\end{tabular}

OM: Organic matter

Table 2: Chemical characteristics of Sewage Sludge

\begin{tabular}{|c|c|}
\hline Parameters & Units \\
\hline Organic matter (\%) & 49.27 \\
\hline Electrical conductivity $\left(\mathrm{dSm}^{-1}\right)$ & 3.71 \\
\hline $\mathrm{pH}\left(\mathrm{CaCl}_{2}\right)$ & 6.98 \\
\hline $\mathrm{pH}$ (water) & 7.14 \\
\hline Olsen P (mg kg $\left.{ }^{-1}\right)$ & 1.21 \\
\hline Available $\mathrm{K}\left(\mathrm{mg} \mathrm{kg}^{-1}\right)$ & 2.91 \\
\hline Available $\mathrm{S}\left(\mathrm{mg} \mathrm{kg}^{-1}\right)$ & 381 \\
\hline N (Kjeldhal) $\left(\mathrm{g} \mathrm{kg}^{-1}\right)$ & 38.9 \\
\hline Cation exchange capacity (cmolc $100 \mathrm{~g}^{-1}$ ) & 94.9 \\
\hline Al-saturation (\%) & 0.02 \\
\hline Al-extractable $\left(\mathrm{mg} \mathrm{kg}^{-1}\right)$ & 90 \\
\hline
\end{tabular}

p-nitrophenol released from $p$-nitrophenyl -beta-D-glucopyranoside according to Eivazi and Tabatabai (1990). One unit of enzyme activity was defined as $1 \mu \mathrm{mol}$ of product released per $\min$ (IU). The average and standard deviations of enzymatic activities from triplicate culture are reported.

\section{Statistical analysis}

The values were arcsine transformed before statistical analysis. The data were analysed by factorial analysis of variance with AM fungi treatment, SS treatment and their interaction as sources of variation. 
Statistical procedures were carried out with the SPSS software, version 11.0 (SPSS Inc., 1989-2001). Statistical significance was determined at $\mathrm{P}<0.05$.

\section{RESULTS}

The results of factorial ANOVA are given in Table 3. FDA activity was significantly increased by AM treatments and the interaction between $\mathrm{AM}$ and SS. The $\beta$ glucosidase activity was significantly increased by AM and SS treatments. All the treatments and their interactions (AMxSS) increased shoot dry weight. At the end of the study the mycorrhizainoculated seedlings were significantly larger. The biomass of inoculated plants with all AM fungi was greater than uninoculated plants (Figure 1). This beneficial effect was more evident with the $G$. viscosum inoculation. In the other hand, the addition of SS also increased the shoot dry weight of E. globulus. In fact, the shoot biomass was significantly increased at $6 \mathrm{~g}$ of $\mathrm{SS}$ treatment. In addition, this beneficial effect was more evident and significantly increased with the interaction between $G$. viscosum inoculation plants and the application of 4 $\mathrm{g}$ of SS to100 $\mathrm{g}^{-1}$ of soil. The root dry weight of E. globulus was not stimulated in soil inoculated or not with all the AM fungi (Figure 1). The application of SS at $8 \mathrm{~g}$ to $100 \mathrm{~g}$ of soil decreased the root dry weight inoculated or not with the AM fungi.

The effects of the interaction between SS and E. globulus inoculated wit AM fungi on the $\mathrm{N}$ contents in plant shoot are illustrated in Figure 2A. The AM fungi $G$. claroideum and $G$. viscosum have a significant increase in the $\mathrm{N}$ contents of the plant tissues. $G$. intraradices and $G$. constrictum did not produce differences in $\mathrm{N}$ contents on plant shoot. The $\mathrm{N}$ content was also higher when E. globulus were inoculated with $G$. viscosum and SS were applied in the same treatment. The effects of SS and E. globulus inoculated with AM fungi on the $\mathrm{P}$ contents are illustrated in Figure 2B. The P contents on plant shoot were significantly higher in all treatment with SS application. This effect was also observed on plants inoculated with the all AM fungi. In this case, the AM fungi $G$. claroideum, $G$. viscosum and $G$. intraradices showed an increased of 2 to $8 \mathrm{~g}$ of SS to $100 \mathrm{~g}$ of soil in P content on plant shoot.

The average mycorrhizal root colonization of plants inoculated with $G$. claroideum, G. viscosum and $G$. intraradices was $67 \%, 59 \%$ and $67 \%$ of total root length, whereas the AM colonization was unaffected $(8 \%)$ in plants inoculated with $G$. constrictum (Fig. 3A). The effect of SS in mycorrhizal root colonization of E. globulus decreased in presence of 2, 4, 6 and $8 \mathrm{~g}$ of SS to 100 g-1 of soil applied. The interaction between SS and E. globulus inoculated with $G$. intraradices increased the AM colonization in presence of 2, 4 and $6 \mathrm{~g}$ of SS to $100 \mathrm{~g}$ of soil.

The metabolic activity of the AM fungi, measured as SDH activity of the fungal mycelium inside the root of $E$. globulus showed the same effect for 0 and $2 \mathrm{~g}$ of SS to $100 \mathrm{~g}$ of soil applied (Fig. $3 \mathrm{~B})$. The sewage sludge decreases the metabolic activity of the AM fungi. Nevertheless, $4 \mathrm{~g}$ of SS to $100 \mathrm{~g}^{-1}$ of soil applied shows unaffected the $\mathrm{SDH}$ activity in plants inoculated with $G$. claroideum, $G$. viscosum and $G$. intraradices. 
Table 3: $F$-values and significance for the main treatment effects and their interactions, based on a bifactorial ANOVA

\begin{tabular}{lccc}
\hline Variables & AM & SS & AM*SS \\
\hline Shoot dry weight & $53.21 * *$ & $275.28 * *$ & $11.03 * * *$ \\
Root dry weight & 21.33 n.s. & 197.41 n.s. & 4.17 n.s. \\
FDA & $47.58 * *$ & 164.35 n.s. & $10.06 * *$ \\
$\beta$-glucosidase & $24.27 * *$ & $239.482 * *$ & 12.73 n.s. \\
\hline
\end{tabular}

AM: Arbuscular mycorrhiza; SS: Sewage sludge. Significance conventions: ns=not significant;* $P<0.05 ; * * P<0.01 ; \quad * * * P<0.001$.

Fluorescein diacetate activity was increased by the inoculation with all AM fungi and this effect was more evident in treatment with the arbuscular mycorrhizal fungus G. viscosum (Figure 4A). The application of this sewage sludge at different doses did not affect the FDA hydrolysis in E. globulus plants. In contrast, the inoculation with $G$. viscosum in presence of sewage sludge increased FDA activity.

The $\beta$-glucosidase activity in the rhizosphere of E. globulus plant was increased only in the presence of SS to 2$6 \mathrm{~g}$ to $100 \mathrm{~g}$ of soil (Figure 4B). The most important increased of $\beta$-glucosidase was the inoculation with $G$. viscosum in presence of sewage sludge to $4 \mathrm{~g}$ of SS to $100 \mathrm{~g}^{-1}$ of soil but significantly higher at 6 and $8 \mathrm{~g}$ of SS to $100 \mathrm{~g}$ of soil.

\section{DISCUSSION}

The aim of this study was to investigate determine the effect of SS and mycorrhizal inoculation on the plant growth promotion and how could affect the plant nutrition and some soil biological properties. Our results confirm, in general, as was previously described, a positive plant growth response to organic amendments (Muthukumar and Udaiyan, 2000). Increases in growth may be attributable in part to higher net mineralization of adequate nutrients (Antolin et al., 2005) in particular the $\mathrm{N}$ mineralization from this SS (Khan and Scullion, 2000).

The shoot dry weights of E. globulus colonized by all AM fungi assays and with application to SS, in general, were significantly increased. Bestel-Corre et al. (2004) found that the application of municipal SS in plants of Medicago truncutula non-inoculated with G. mosseae improved the plant biomass more than those inoculated with this mycorrhizal fungus. Sullivan et al. (2006) reported a decrease of AM associations with an increase of the application rate of SS due directly to nutrient content or indirectly through the effects of SS on plant community species richness and structure. In fact, in our experiments we observed a decrease of AM colonization and SDH activity of the intraradical fungal mycelium of E. globulus by all the treatments with SS application. In the other hand, Alguacil et al. (2006) found 


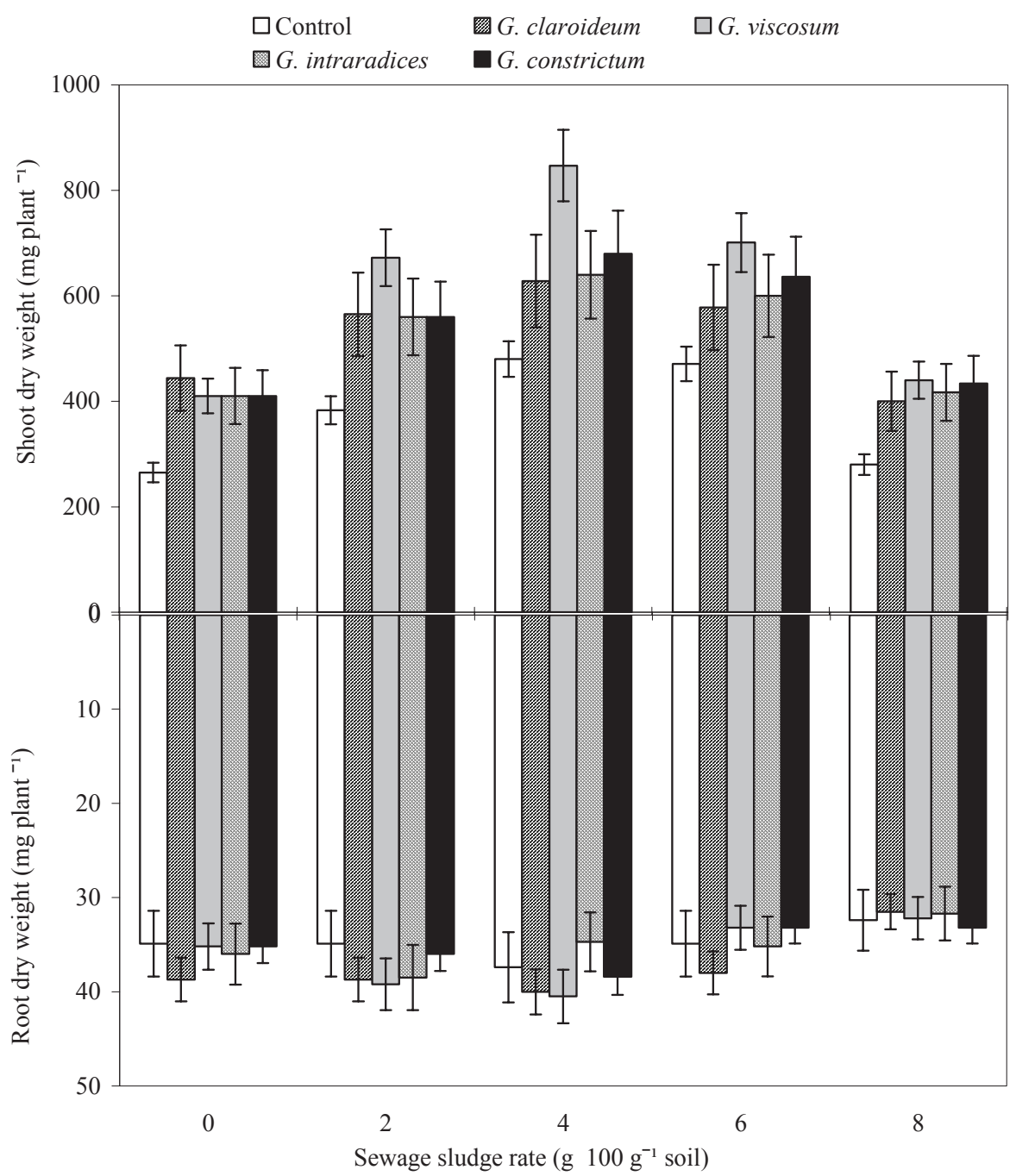

Figure 1: Shoot and root dry weight (mg plant $\left.{ }^{-1}\right)$ of Eucalyptus globulus inoculated with the arbuscular mycorrhizal fungi Glomus claroideum, G. viscosum, G. intraradices and $G$. constrictum in soil amended with sewage sludge. The data are the means \pm standard error $(\mathrm{n}=10)$

that the inoculation with AM fungi and the addition of SS significantly stimulated growth of Juniperus oxycedrus (shoot and root dry weights) and the $\mathrm{N}$ and $\mathrm{P}$ contents in shoot tissues, with respect to the non-inoculated and non-treated with
SS plants. The FDA activity was not stimulated for the SS application to control treatments (without the inoculation with $\mathrm{AM}$ ). It has been reported that large fertilizer additions have led to reductions in microbial 
Effect of arbuscular mycorrhiza on Eucalyptus globulus, Arriagada et al.
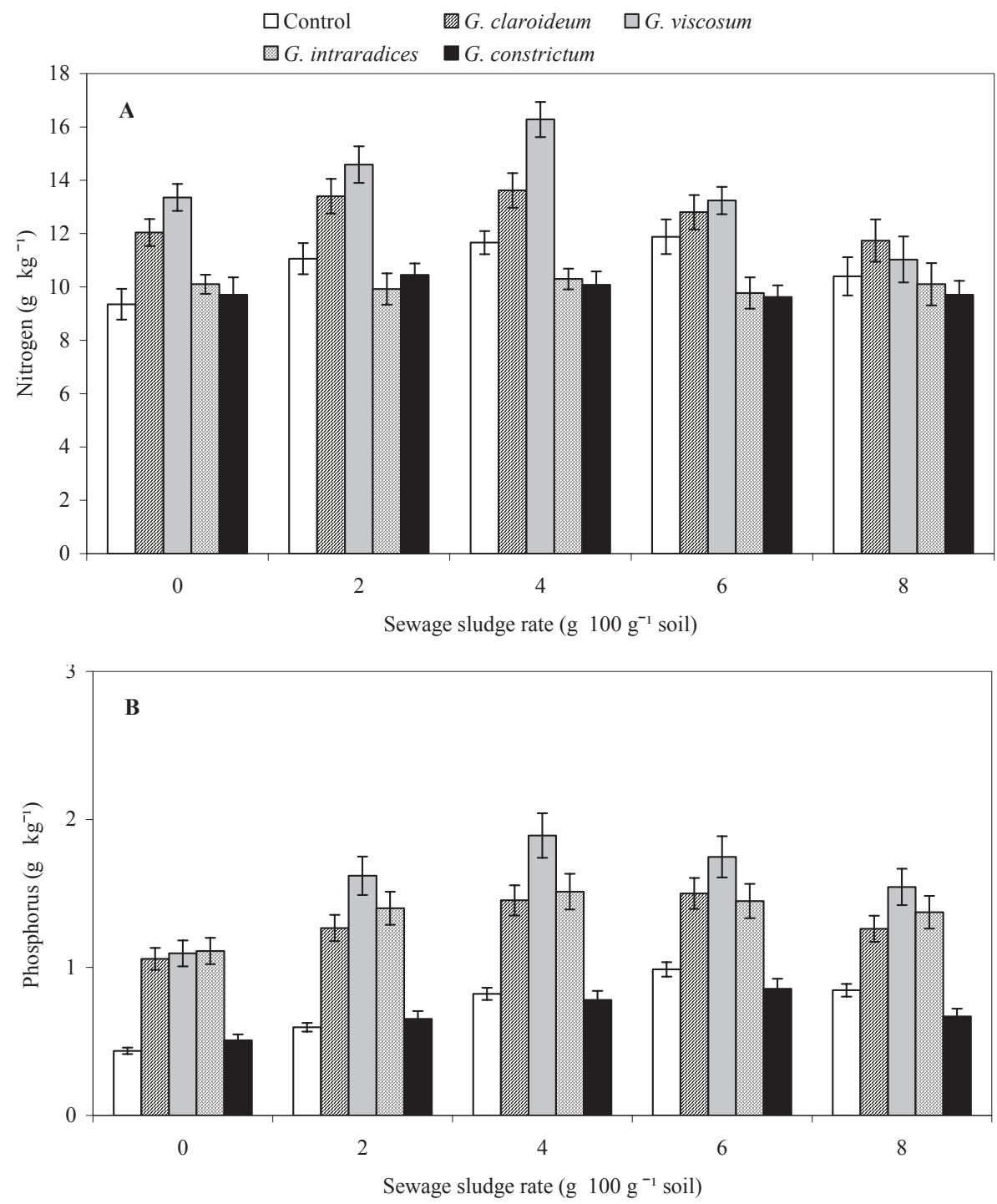

Figure 2: Nitrogen (A) and phosphorus (B) in shoot of Eucalyptus globulus plants (g $\mathrm{kg}^{-1}$ ) inoculated with the arbuscular mycorrhizal fungi Glomus claroideum, $G$. viscosum, G. intraradices and G. constrictum in soil amended with sewage sludge. The data are the means \pm standard error $(\mathrm{n}=10)$ 

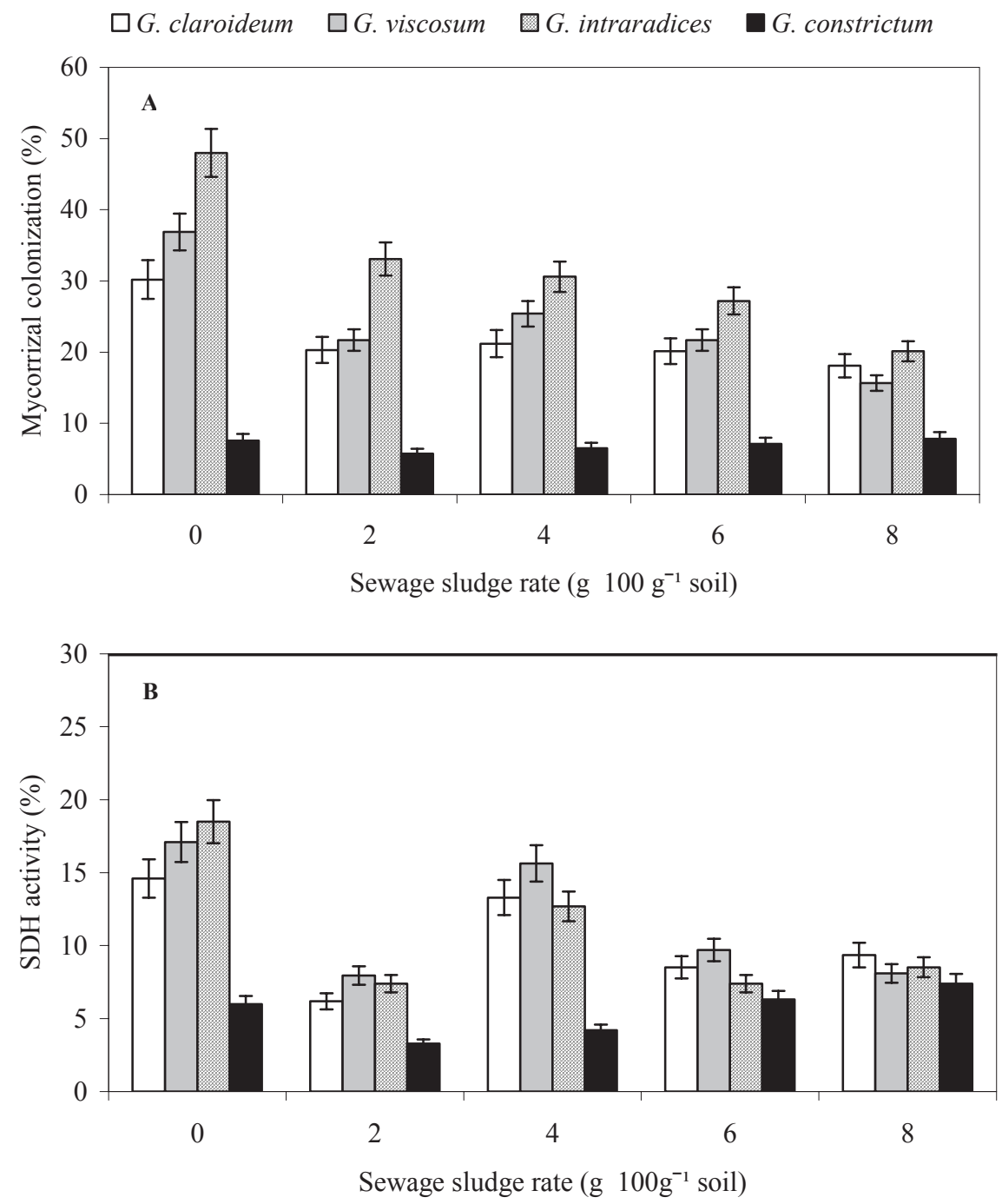

Figure 3: Percentage of mycorrhizal root colonization (A) and Arbuscular mycorrhizal intraradical mycelium with succinate dehydrogenase (SDH) activity (B) of Eucalyptus globulus inoculated with the arbuscular mycorrhizal fungi Glomus claroideum, $G$. viscosum, $G$. intraradices and $G$. constrictum in soil amended with sewage sludge. The data are the means \pm standard error $(\mathrm{n}=10)$ 
Effect of arbuscular mycorrhiza on Eucalyptus globulus, Arriagada et al.
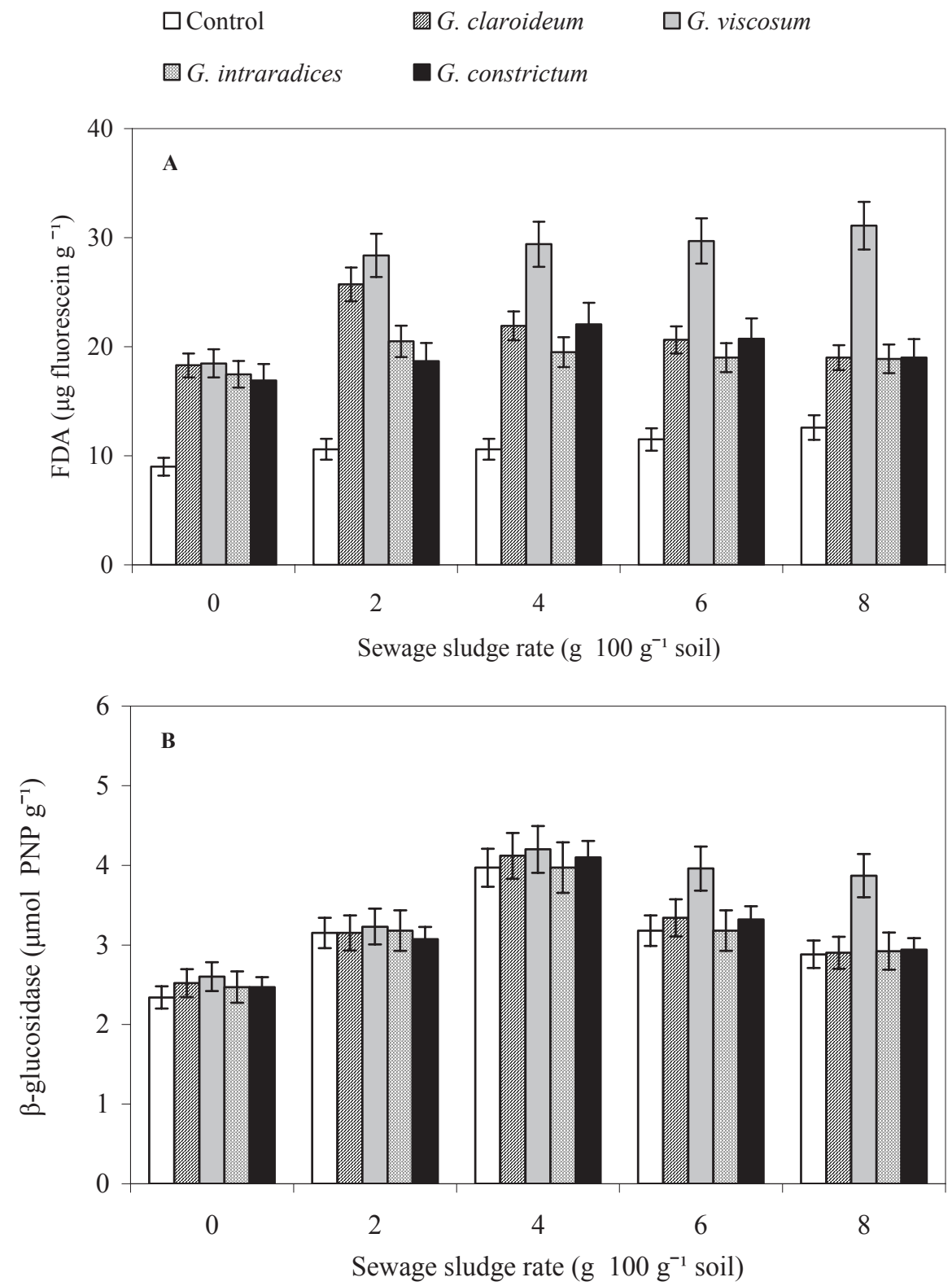

Figure 4: Fluorescein diacetate (FDA) ( $\mu$ g fluorescein $\left.g^{-1}\right)(A)$ and $\beta$-glucosidase ( $\mu$ mol PNP g-1) (B) activities in the rhizosphere soil of Eucalyptus globulus plants inoculated with the arbuscular mycorrhizal fungi Glomus claroideum, G. viscosum, $G$. intraradices and $G$. constrictum in soil amended with sewage sludge. The data are the means \pm standard error $(\mathrm{n}=10)$ 
activity, which have been attributed, at least partially, to changes in $\mathrm{pH}$ (Insam and Palojärvi, 1995). It is necessary to consider that soil $\mathrm{pH}$ is 5.26. This $\mathrm{pH}$ causes an increase of the proton and chloride presence, which undoubtedly causes an initial decrease of the bacterial biomass, which is better developed at alkaline $\mathrm{pH}$, it seems unlikely that these $\mathrm{pH}$ variations would be sufficiently great to cause differences in biological activity (García et al., 1994).

Pascual et al. (2007) reported that after addition of $\mathrm{SS}$ to soil significantly enhanced the $\beta$-glucosidase activity, probably because SS has a high amount of utilizable substrates for microbial growth (Ros et al., 2003). Medina et al. (2006) observed an increased of $\beta$-glucosidase activity by inoculation with Glomus mosseae and agrowaste amendment. According to our experiments, in the soil with application of SS and inoculated with G. viscosum we observed an important enzymatic activity, thus suggesting the important role of this fungus in the soil organic matter mineralization.

Many authors suggest that increasing on plant biomass to organic amendments can be attributed to enhanced nutrient status (Muthukumar and Udaiyan, 2000; Alguacil et al. 2006; Medina et al., 2006). In order to our experiments, the inoculation with $G$. viscosum increased N and $\mathrm{P}$ in plants. The application of SS also increased soil fertility and rapidly increased the shoot $\mathrm{N}$ and $\mathrm{P}$ contents of $E$. globulus. Therefore, improved plant growth appears to be due to a direct nutrient supply by organic mineralization of SS (Antolin et al., 2005), and by the beneficial effects of AM inoculation (Alguacil et al., 2006; Medina et al., 2006).

\section{CONCLUSION}

In conclusion the SS from municipal wastewater used in this study improves the soil fertility due to high content of organic and inorganic plant nutrients. The application of SS to E. globulus inoculated with AM fungi showed results very variable in the plant biomass production and the enzymes activities. Sewage sludge application improved some soil enzymes activities and plant nutrition. In particular conditions, some authors indicated that the application amounts of SS could be used for several years to maintain crop production. In this study, the application of certain amounts of SS does not cause problems to $E$. globulus, but the applied amounts have to be taken into account in future bioassays planning with other plants. These bioassays can be a suitable tool to evaluate the beneficial effects of $\mathrm{SS}$ as soil amendments with beneficial impacts on E. globulus plant growth.

\section{ACKNOWLEDGEMENTS}

This work was financied by the Fondo Nacional de Desarrollo Científico y Tecnológico (FONDECYT), grant 1060390, and DIUFRO 08-0065.

\section{REFERENCES}

Adam, G., Duncan H. 2001. Development of a sensitive and rapid method for the measurement of total microbial activity using fluorescein diacetate (FDA) in a range of soils. Soil Biology and Biochemistry. 33, 943-951. 
Effect of arbuscular mycorrhiza on Eucalyptus globulus, Arriagada et al.

Alguacil, M., Caravaca, F., Díaz-Vivancos, P., Hernández, J., Roldán, A. 2006. Effect of arbuscular mycorrhizae and induced drought stress on antioxidant enzyme and nitrate reductase activities in Juniperus oxycedrus L. grown in a composted sewage sludge-amended semi-arid soil. Plant and Soil. 279, 209-218.

Antolin, M., Pascual, I., García, C., Polo, A., Sánchez-Diaz, M. 2005. Growth, yield and solute content of barley in soils treated with sewage sludge under semiarid Mediterranean conditions. Field Crops Research. 94, 224-237.

Arriagada, C., Herrera M., García-Romera, I., Ocampo, J. 2004. Tolerance to $\mathrm{Cd}$ of soybean (Glycine max) and eucalyptus (Eucalyptus globulus) inoculated with arbuscular mycorrhizal and saprobe fungi. Symbiosis. 36, 285-299.

Arriagada, C., Herrera M., Ocampo, J. 2005. Contribution of arbuscular mycorrhizal and saprobe fungi to the tolerance of Eucalyptus globulus to $\mathrm{Pb}$. Water Air and Soil Pollution. 166, 31-47.

Banerjee, M., Burton, D., Depoe, S. 1997. Impact of sewage sludge application on soil biological characteristics. Agricultural Ecosystem and Environment. 66, 241-249.

Baon, J., Smith, S., Alston, A., Wheeler, R. 1992. Phosphorus efficiency of three cereals as related to indigenous mycorrhizal infection. Australian Journal of Agricultural Research. 43, 479-491.

Bestel-Corre, G., Gianinazzi, S., Dumas-Gaudot, E. 2004. Impact of sewage sludges on Medicago truncatula symbiotic proteome. Phytochemistry. 65, 1651-1659.

Cliquet, J.B., Stewart G.R. 1993. Ammonia assimilation in Zea mays L. infected with a vesicular-arbuscular mycorrhizal fungus Glomus fasciculatum. Plant Physiology. 3, 865-871.

Cuevas, G., Blázquez, R., Martinez, F., Walter, I. 2000. Composted MSW effects on soil properties and native vegetation in a degraded semiarid shrubland. Compost Science and Utilization. 8, 303309.
Dick, W.A., Tabatabai, M.A. 1977. Determination of orthophosphate in aqueous solutions containing labile organic and inorganic phosphorus compounds. Journal of Environmental Quality. 6, 82-85.

Dane, J., Topp, C. 2002. Methods of Soil Analysis, Part 4, Physical Methods; SSSA: Madison, WI, SSSA Book Series, No. 5.

Eivazi, F., Tabatabai, M. 1990. Factors affecting glucosidase and galactosidase activities in soils. Soil Biology and Biochemistry. 22, 891- 7 .

Feng, G., Zhang, F., Li, X., Tian, C., Tang, C, Rengel, Z. 2002. Improved tolerance of maize plants to salt stress by arbuscular mycorrhiza is related to higher accumulation of soluble sugars in roots. Mycorrhiza. 12, 185-190.

García, C., Hernández, T., Costa, F. 1994. Microbial activity in soils under Mediterranean environmental conditions. Soil Biology and Biochemistry. 26, 1185-1191.

García-Gil, J., Plaza, C., Senesi, N., Brunetti, G. 2004. Effects of sewage sludge amendment on humic acids and microbiological properties of a semiarid Mediterranean soil. Biology and Fertility of Soils. 39, 320-328.

Giovannetti, M., Mosse, B. 1980. An evaluation of techniques for measuring vesicular-arbuscular mycorrhizal infection in roots. New Phytologist. 84, 489-500.

Insam, H., Palojärvi, A. 1995. A microcosms experiment on the effects of forest fertilization on nitrogen leaching and soil microbial properties in the northern calcareous alps of Austria. Plant and Soil. 75-81.

Jackson, M. 1973. Soil Chemical Analysis, Prentice Hall, New Delhi India, 393p.

Joner, E., Leyval, C. 1997. Uptake of Cd-109 by roots and hyphae of a Glomus mosseae Trifolium subterraneum mycorrhiza from soil amended with high and low concentrations of cadmium. New Phytologist. 135, 353-360. 
Khan, M., Scullion, J. 2000. The effect of soil on microbial responses to metals in sludge. Environmental Pollution. 110, 115-125.

Kourtev, P., Ehrenfeld, J., Haggblom, M. 2003. Experimental analysis of the effect of exotic and native plant species on the structure and function of soil microbial communities. Soil Biology and Biochemistry. 35, 895-905.

MacDonald, R., Lewis M. 1978. The occurrence of some acid-phosphatases and dehydrogenases in the vesicular-arbuscular mycorrhizal fungus Glomus mosseae. New Phytologist. 80, 135-141.

Mata-González, R., Sosebee, R., Wan, C. 2002. Shoot and root biomass of desert grasses as affected by biosolids application. Journal of Arid Environments. 50, 477-488.

Medina, A., Vassileva, M., Barea. J., Azcon, R. 2006. The growth-enhancement of clover by Aspergillus-treated sugar beet waste and Glomus mosseae inoculation in $\mathrm{Zn}$ contaminated soil. Applied Soil Ecology. 33, 87-98.

Muthukumar, T., Udaiyan, K. 2000. Arbuscular mycorrhizas of plants growing in the Western Ghats region, southern India. Mycorrhiza. 9, 297-313.

Ocampo, J.A., Barea, J.M. 1985. Effect of carbamate herbicides on VA mycorrhizal infection and plant growth. Plant and Soil. 85, 375-383.

Olsen, S.R, Sommers, L.E. 1982. Phosphorus. In: A. L. Page (editor): Methods of soil analysis. Part 2. ASA - SSSA, Wisconsin, p. 403-430.

Oudeh, M., Khan, M., Scullion, J. 2002. Plant accumulation of potentially toxic elements in sewage sludge as affected by soil organic matter level and mycorrhizal fungi. Environmental Pollution. 116, 293.
Pascual, I., Antolin, C., García, C., Polo, A., Sánchez-Díaz, M. 2007. Effect of water deficit on microbial characteristics in soil amended with sewage sludge or inorganic fertilizer under laboratory conditions. Bioresource Technology. 98, 29-37.

Pearson, J., Jakobsen I. 1993. The relative contribution of hyphae and roots to phosphorus uptake by arbuscular mycorrhizal plants, measured by dual labelling with $32 \mathrm{P}$ and 33P. New Phytologist. 124, 489-494.

Phillips, J.M., Hayman, D.S. 1970. Improved procedures for clearing roots and staining parasitic and vesicular-arbuscular mycorrhizal fungi for rapid assessment of infection. Transaction British Mycological Society. 55, 158-161.

Rate, A., Lee, K., French, P. 2004. Application of biosolids in mineral sands mine rehabilitation: use of stockpiled topsoil decreases trace element uptake by plants. Bioresource Technology. 91, 223-231.

Ros, M., Hernández, M., García, C. 2003. Soil microbial activity after restoration of a semiarid soil by organic amendments. Soil Biology and Biochemistry. 35, 463-469.

Shetty, K.G., Hetrick, B.A., Figge, D.A., Schwab, A.P. 1994. Effects of mycorrhizae and other soil microbes on revegetation of heavy-metal contaminated mine spoil. Environmental Pollution .86, 181-188.

Sullivan, T.S., Stromberger, M.E., Paschke, M.W. 2006. Parallel shifts in plant and soil microbial communities in response to biosolids in a semi-arid grassland. Soil Biology and Biochemistry. 38, 449-459. 